Abstracta Iranica Abstracta Iranica

Revue bibliographique pour le domaine irano-aryen

Volume 26 | 2005

Comptes rendus des publications de 2003

\title{
« Nouveaux trésors de monnaies phéniciennes (CH IX) ». Transeuphratène, 26, Gabalda, Paris, (2003), pp. 105-120.
}

\section{Astrid Nunn}

\section{(2) OpenEdition}

1 Journals

Édition électronique

URL : http://journals.openedition.org/abstractairanica/3301

DOI : 10.4000/abstractairanica.3301

ISSN : 1961-960X

Éditeur :

CNRS (UMR 7528 Mondes iraniens et indiens), Éditions de l'IFRI

Édition imprimée

Date de publication : 15 mai 2005

ISSN : 0240-8910

Référence électronique

Astrid Nunn, « « Nouveaux trésors de monnaies phéniciennes (CH IX) ». Transeuphratène, 26, Gabalda, Paris, (2003), pp. 105-120. », Abstracta Iranica [En ligne], Volume 26 | 2005, document 97, mis en ligne le 08 décembre 2005, consulté le 25 septembre 2020. URL : http://journals.openedition.org/ abstractairanica/3301; DOI : https://doi.org/10.4000/abstractairanica.3301

Ce document a été généré automatiquement le 25 septembre 2020.

Tous droits réservés 
« Nouveaux trésors de monnaies phéniciennes (CH IX)». Transeuphratène, 26, Gabalda, Paris, (2003), pp. 105-120.

\author{
Astrid Nunn
}

En 1993 paraissait la publication du corpus de 75 trésors contenant des monnaies phéniciennes d'époque achéménide. Ses auteurs J. Elayi et A. G. Elayi offrent ici une seconde réactualisation qui nous mène au nombre total de 82 trésors.

INDEX

Thèmes : 3.2.2. Pré-Achéménides et Achéménides

\title{
AUTEURS
}

ASTRID NUNN

Université de Munich 